\title{
THE EFFECT OF SEMANTIC MAPPING STRATEGY ON STUDENTS' READING COMPREHENSION AT THE NINTH GRADE STUDENTS OF SMP RAKSANA MEDAN
}

\author{
Resniaty Situmorang \\ Prima Indonesia University
}

\begin{abstract}
This research is aimed to investigate the effect of semantic mapping strategy on students' reading comprehension of narrative text and the significant different on reading comprehension of narrative text between two groups: who are teach using semantic mapping strategy and those who are teach using conventional method. The design of the study is experimental study. The population of this study is the ninth grade students of SMP Raksana Medan in the academic year of 2014/2015. The number of the subjects is 60 students. The data are obtained by administering reading test to the IX-1 as experimental group and IX-2 as control group. The research is started by giving pre-test, treatment and post-test to both experimental and control groups. The data of the test are analyzed by using t-test formula to know the difference of the students' comprehension in reading narrative text between two groups. In the pre-test the mean score of the experimental group is 54 and the control group is 53.67. The result of post-test of the experimental group is 78.33 and the control group is 67.5. The result of the t-test of mean difference is 3.046 and t- table is $2.00 \mathrm{It}$ means that $\mathrm{t}$-value is higher than $\mathrm{t}$-table $(3.046>2.00)$. The calculation revealed that the hypothesis about a significant difference on reading comprehension between students who are teach narrative text by using semantic mapping strategy and those who are taught by using conventional method is accepted. It can be concluded that Semantic Mapping Strategy worked effectively to help students increase their achievement in reading comprehension. It is suggested that teachers of English apply Semantic Mapping Strategy as one of the alternatives in teaching reading comprehension.
\end{abstract}

Keywords: Semantic Mapping strategy, reading comprehension, students of SMP Raksana Medan

\section{INTRODUCTION}

Reading skill is one of the most important aspects to be taught in school in order to enable the learners to grasp the meaning from the reading text. It is a foundation skill for the learning, personal growth, and enjoyment. As one of the language skills, reading also plays an important role because reading has become a part of our daily life.

Through reading various printed material such as newspaper, magazine, fiction and nonfiction book we are able to gain a lot of knowledge, information, and pleasure and problem solution. By reading comprehension, the students are able to gain and increase their knowledge. Nunan (2003:68) states, "Reading is a fluent process of readers combining information from a text and their own background knowledge and build meaning."

Reading is one of the four basic skills in learning a language besides listening, speaking and writing. Reading is an essential skill for all students at all levels. Burns, Roe and Ross (1984:8) state," Reading is not a single skill but a combination of much skill leading to deriving meaning from print and to the enjoyment of sharing another person's insights."

There are several reasons why students are weak on reading. In order to quench the curiosity about the factors, which causes the weaknesses on reading skills among students, many interested party had conducted a research on this area. Among of them are Arbaiyah \& Zaidah (2001) who found that students are less efficient in reading because they lack independent reading. These students always have problem in reading. It is 
anticipated them to read less compare to the students who have skill in reading. In other words, if the students read rarely, they might have problem in acquiring vocabulary. Secondly, students are unable to use context clues to guess the word meaning. If the students come across with difficult words, they tend to ignore the words and it makes them discouraged and stops reading. The last factor is that they do not converse in English outside the classroom; as the result they don't have the ability to express their idea in English.

From the writer's observation toward the ninth grade students of SMP Swasta Raksana Medan Class IX-1 and Class IX-2 in the Academic Year of 2014/2015 when they were learning in the classroom, the students are not motivated to learn English subject particularly reading. The writer observed that when the teacher asked the students to follow him to read a text, there are many students did not read the text, even, there are students took a nap.

After the text was read by the students the teacher asked the students to translating the text. The students kept looking up in their dictionaries to find out the meanings of the difficult words. The students who do not have dictionaries asked the meanings of the difficult words to their friends who have dictionaries. It made the class very loud. Besides, there are some students who did not do anything. The students have difficulties to comprehend a reading text. They can read the reading text well but cannot comprehend what the text is. As a result, they do not progress in reading comprehension. They also do not answer the following questions about a reading text well because the students had lack of motivation and vocabulary.

Comprehension in reading session is a goal that students should achieve to measure their understanding of a text in their learning process when they read and find out the meaning of the text. The students need a method or strategy to make them comfortable and easy to comprehend a text. In fact teachers who teach at schools still use the conventional method. Teachers translate all the texts that because students do not try to translate the texts by themselves.

These problems invited the writer to find a strategy in order to solve them. The writer chose semantic mapping strategy as the strategy which is used to solve the problem. Semantic mapping strategy has significant effects on teaching reading comprehension. Semantic mapping strategy which can be a visual representation of knowledge that supports students to create their own understanding of certain text into their own work by drawing a figure, table or chart which the represented the content of the text (Zaid, 1995:6).

Heimlich \& Pittelman (1986:44) stated that present a set of advantages related to the semantic mapping strategy. There is the advantages of semantic mapping strategy are motivating students all of grade levels, integrating thinking with reading, integrating assessment with teaching and making judgments concerning the appropriate instruction needed.

Semantic mapping strategy can be used to solve the problems faced by students in comprehending reading texts. Besides, it is also expected to increase the students' level from low level to higher level. Generally, semantic mapping strategy helps students activate their knowledge about a related topic which is given by teachers and also it may motivate the students to improve their interest in reading ability with a pleasure not only read one type of text but also they can be enthusiastic for other many kind of text.

This strategy assists teachers to find the appropriate instruction that can help them identify the pattern of organization of ideas and concepts. It can be useful for introducing the important vocabulary in a selection to be read. It shows students how the terms are related. In this case, students are given an opportunity to mention all the vocabularies that are related to the topic. By using this strategy, students are taught how to master reading and vocabulary together easily because it can help them clarify complicated points they read. Therefore this research was conducted in order to find out whether semantic mapping strategy significantly affects students' reading comprehension. 


\section{REVIEW OF LITERATURE}

\subsection{Reading}

Most people read without giving much thought to how they do it. To them, What is reading? is a question of little concern. One's concept of what reading is, however, should be a major concern to the person whose primary task is to teach reading. Heilman, Blair and Rupley (1981:4) stated,

1. reading is interacting with language that has been coded into print,

2. the product of interacting with the printed language should be comprehension,

3. reading ability is closely related to oral language ability,

4. reading is an active and ongoing process that is affected directly by an individual's interaction with his environment.

Reading should be made as a habit. By reading, one can get much knowledge that will be useful in many aspect of human life. Nunan (2003:68) states that reading is a fluent process of readers to combine information from a text and their own background knowledge to building meaning. Based on the definition above, it can be concluded that reading is a complex process of thinking in assigning material which involves most of the readers' comprehension in order to get ideas or information extended by the text. Grabe and Stoller (2002:9) state that reading is the ability to draw meaning from printed page and interpret this information appropriately.

From the quotation above, reading means to find out the message or required information that the writer put into the text as efficiently as possible. Nunan (2003: 68) states, "Reading is a fluent process of readers combining information from a text and their own background knowledge and build meaning". Reading is an essential skill for learners of English as a Second Language. For most of these learners it is the most important skill to master in order to ensure success not only in learning English, but also in learning in any contents class where reading in English is required.

\subsubsection{Reading Process}

Nunan (2003:70-73) argued that the models of reading process can be divided into three categories; they are bottom-up models, top-down models and interactive models. The follwing are the explanations of the three models of the reading process.

\subsubsection{Bottom-up Models}

Bottom-up models typically consist of lower reading processes. Students start with the fundamental basics of letter and sound recognition, which in turn allows for morpheme recognition followed by word recognition, building up to the identification of grammatical structures, sentences and longer text, and finally meaning is the order in achieving comprehension. All reading material is carefully reviewed so that students are not exposed to vocabulary that is too difficult or that contains sounds that they have not yet been introduced to. Figure 2.1 is a graphic representation of a bottom-up approach to reading. The readers begin with the smallest elements and builds up to comprehension of what is being read.

All reading material is carefully reviewed so that students are not exposed to vocabulary that is too difficult or that contains sounds that they have not yet been introduced to. Figure 2.1 is a graphic representation of a bottom-up approach to reading. The readers begin with the smallest elements and builds up to comprehension of what is being read. 


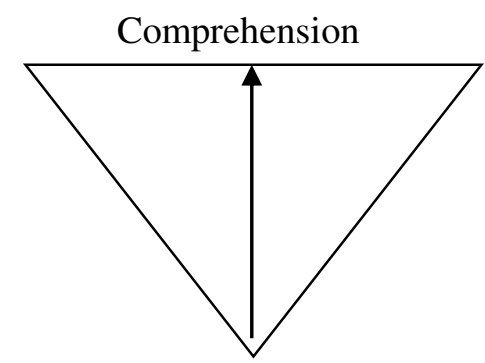

Figure 2.1: Bottom-up approach to reading

Within a bottom-up approach to reading, the most typical classroom focus is on what we call intensive reading. Intensive reading involves a short reading passage followed by textbook activities to develop comprehension and/or a particular reading skill. Most textbooks used to teach first and second language reading use an intensive reading approach (Nunan, 2003:70-71).

\subsubsection{Top-down Models}

Top-down models, on the other hand begin with the idea that comprehension resides in the reader. The reader uses background knowledge, makes predictions and searches the text confirm or reject the predictions that are made. A passage can thus be understood even if all of the individual words are not understood. Within a top down approach to reading the teacher should focus on meaning generating activities rather than on mastery of words recognition. Figure 2.2 is a graphic representation of top down approach to reading. The reader begins with the largest elements and works down toward smaller elements to build comprehension of what is being read.

Reading begins with reader background knowledge

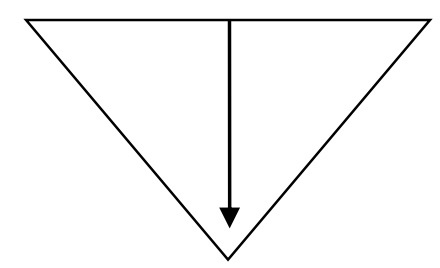

Figure 2.2: Top-down approach to reading

Extensive reading place is a key in rule top-down approaches to reading. Extensive reading can be contrasted with intensive reading. Extensive reading means reading many books (for longer segments text) without a focus on classroom exercise that may test comprehension skills (Nunan, 2003:71-72).

\subsubsection{Interactive Models of Reading}

The models that are accepted as the most comprehensive description of the reading process are interactive models. This third type combines elements of what bottom-up and top-down models assuming "that a pattern is synthesized basic on information provided simultaneously from several knowledge sources". Figure 4 is a graphic a presentation of an interactive approach to reading. The reader combines elements of both bottom-up and top-down models of reading reach comprehension. 
Reader background knowledge

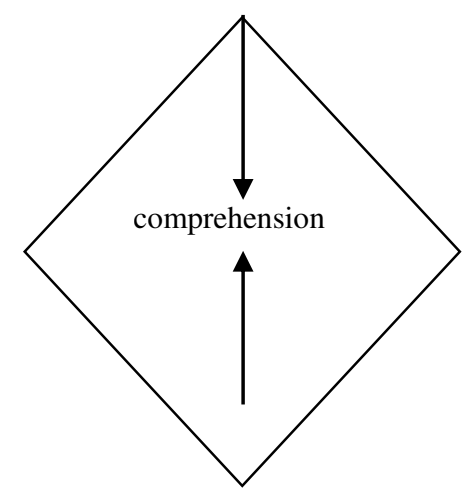

Individual letters and sound

Figure 2.3: Interactive approach to reading

An interactive approach to reading would include aspects of both intensive and extensive reading. We need to provide learners with shorter passages to teach specific reading skills and strategies explicitly. We also need to encourage learners to read longer texts without an emphasis on testing their skills. Extensive reading provides of opportunities to practice strategies introduced during extensive reading instruction (Nunan, 2003:72-73). Teacher should be aware that a single classroom textbook will not meet the needs for both intensive and extensive instruction. Materials will need to be selected that engage the learners in both types of reading.

\subsubsection{The Purposes of Reading}

When we begin to read, we actually have a number of initial decision to make, and we usually make this decisions very quickly, unconsciously in most cases. We read partly for information, but we also read with a goal to finish the text. Here we might read a novel, short story, a newspaper article or a report text of some type to understand the information in the text, to be entertained and/or to use the information for a particular purpose. Grabe and Stoller (2002:13-15) stated the purpose of reading stated that the purposes of reading are classified into:

\section{Reading to search for simple information}

Reading to search for simple information is a common reading ability, though some researchers see it as a relatively independent cognitive process. It is used so often in reading task that it is probably best seen as a type of reading ability. In reading to search, we typically scan the text for a specific piece of information or a specific word.

\section{Reading to skim}

Reading to skim is a common part of many reading tasks and a useful skill in its own right. It involves, in essence, a combination of strategies for guessing where important information might be in the text, and then using basic reading comprehension skills on those segments of the text until a general idea is formed.

\section{Reading to learn from text}

Reading to learn typically occurs in academic and professional contexts in which a person needs to learn a considerable amount of information from a text. It requires abilities to remember main ideas as well as a number of details that elaborate the main and supporting ideas in the text, recognize and build rhetorical frames that organize the information in the text, and link the text to the reader's knowledge base. Reading to learn is usually carried out at a reading rate somewhat slower than general reading comprehension. 


\section{Reading to integrate information, write and critique texts}

Reading to integrate information requires additional decision about the relative importance of complementary, mutual supporting or conflicting information. Reading to write and reading to critique texts may be task variants of reading to integrate information.

\section{Reading for general comprehension}

Reading for general comprehension, when accomplished by a skilled fluent reader, requires very rapid and automatic processing of words, strong skills in forming a general meaning representation of main ideas, and efficient coordination of many processes under very limited time constraints. The overall goal is not to remember most of the specific details but to have a goal grasp of the main ideas and supporting ideas, and to relate those main ideas to background knowledge as appropriate.

\subsection{Reading Comprehension}

The essence of reading activity is comprehension. It becomes a primary challenge in teaching or learning skill. In order to learn or understand the message of the author, the students are hoped to have the ability for comprehending a text. Comprehension means understanding the meaning or the point of a topic. Reading with comprehension means to understand what has been read. It involves taking reading to a text in order to obtain meaning from text. In reading process, comprehension is needed to get the goal of reading. According to Grabe \& Stoller (2002:17), reading ability needs the ability to understand or to gain information from a text. It means reading is not only to get the information, but also it is to comprehend the text. To understand reading comprehension one should begin by analyzing what comprehension involves and how it relates to the entire reading process. Basically, comprehension involves a special kind of thinking process. Turner (1988:160) states," Successful comprehension involves the reader discovering the meaning needed to achieve the particular purposes set for, or by, him. It may be finding a particular piece of information, solving a problem through reading, working to understand an idea, or following a set of directions."

From the explanation above, it can be concluded once students are able to decode, formal instruction should be continued to make them understand what they have read. This will enhance students thinking reading process. Thus, comprehension monitoring skilled and unskilled awareness is important to develop students reading skills.

\subsubsection{Levels of Comprehension}

There are some levels of reading comprehension that can be used to discover the meaning of text. According to Burns, Roe \& Ross (1984:177-191), reading comprehension is divided into four levels. They are literal reading, interpretive reading, critical reading and creative reading. The four levels of comprehension are elaborated as follows:

\subsubsection{Literal Reading}

Burns, Roe \& Ross (1984:177) state, "Reading for literal comprehension, which involves acquiring information that is directly stated in a selection, is important in and itself and is also a prerequisite for higher level understanding." Examples of the skills involved are the ability to follow direction and the ability restate the author material in other words. For instance if the author wrote the man's tarter coat was not effective again the cold a child could show evidence of literal comprehension by saying the man's ragged coat didn't keep him warm.

Recognition stated mind ideas, details, causes and effects and sequences is the basis of literal comprehension, and thorough understanding of vocabulary, sentence meaning, and paragraph meaning is important. Exercises for developing literal comprehension include those described earlier under "units of comprehension" as well as those below: 


\section{Details}

The specific explicitly stated parts of paragraph or passage that contain the basic information are details upon which main ideas, cause and effect relationship, inferences, and soon are built. For example, in the sentence "the man wore a red hat," the fact that a red hat was being worn is one detail that readers must note and remember (Burns, Roe \& Ross: 1984:177).

\section{Main ideas}

As we discuss earlier, the main idea of a paragraph is the central thought around which a whole paragraph is organized. It is often, but not always, expressed in a topic sentence (Burns, Roe \& Ross: 1984:179).

\section{Cause and Effect}

Recognizing and understanding the cause- and-effect relationship in a written passage is an important reading skill. It is considered a literal skill when the relationship is explicitly stated ("Bill stayed out because he was ill"). Teachers can use the following activities when the cause and effect are directly stated in the passage; when they are implied, teachers can use procedures similar to the ones listed in the second on interpretive reading (Burns, Roe \& Ross: 1984:180).

\section{Sequence}

Sequence - the order in which events in a paragraph or passage occur-is signaled by time order words such as now, before, when, yet, after and so on. Children must learn to recognize straightforward chronological sequence as well as flashbacks and other devices that describe events "out of order" (Burns, Roe \& Ross: 1984:180).

\section{Following Directions}

The ability to read and follow directions is a prerequisite for virtually all successful schoolwork. This skill is considered a part of literal reading comprehension. It involves understanding details and sequence; therefore, some of the exercises under those headings are appropriate to use in teaching children to follow written directions (Burns, Roe \& Ross: 1984:182).

Based on the explanation given, literal reading refers to the understanding of ideas and facts that are directly stated by the writer or the author.

\subsubsection{Interpretive Reading}

Burns, Roe \& Ross (1984:183-184) state "Interpretive reading involves reading between the lines or making inferences. It is the process of deriving ideas that are implied rather than directly stated." Skills for interpretive reading include:

1. inferring main ideas of passages in which the main ideas are not directly stated,

2. inferring cause and effect relationships when they are not directly stated,

3. inferring referents of pronouns,

4. inferring referents of adverb,

5. inferring omitted words,

6. detecting mood,

7. detecting the authors' purpose in writing, and

8. drawing conclusions.

Lange (1981:443) in Burn, Roe and Ross ( 1986:184) pointed out that readers make inferences consistent with their schemata, yet it is important to realize that children have less prior knowledge than adults and do not always make inferences spontaneously, event when they possess the necessary background knowledge.

\subsubsection{Critical Reading}

Burns, Roe \& Ross (1984:190-197) state, "Critical reading is evaluating written material-comparing the ideas discovered in the material with known standard and drawing conclusions about the accuracy, appropriateness, and timeliness. Critical thinking can also be promoted at an earlier stage through critical reading of pictures. If children are shown 
pictures that contain inaccuracies, they can identify the mistakes. To foster the critical reading skills in the classroom, teachers can encourage pupils to read with a questioning attitude.

Students demonstrate evaluation when they make judgments about the content of reading selection by comparing it with information provided by the teacher or authorities on the subject, or with their own experience, knowledge or values related to the subject. The following are types of evaluation task:

a. Objective evaluation: judging the soundness of statements or events in the reading material based on the external criteria, such as supporting evidence, reason and logic.

b. Subjective evaluation: making judgments about the statements or events presented based on internal criteria, such as one's biases, beliefs or preference.

c. Judgments of adequacy or validity: judging whether the author's statements is accurate and complete when compared to other sources on that subject.

d. Judgments about appropriateness: determining whether certain selections or parts of selection are relevant on contribute to resolving an issue or a problem.

e. Judgments of worth, desirability or acceptability: judging the suitability of a character's action in a particular incident based on the reader's personal value.

The critical reader must be an active reader, questioning, searching for facts, and suspending judgment until he or she has considered all of the material." Critical reading depends upon literal comprehension and interpretive comprehension, and grasping implied ideas is especially important.

\subsubsection{Creative Reading}

Burns, Roe \& Ross (1984:198-205) state, "Creative reading involves going beyond the material presented by author. According to Helen Huss (1967) in (Burn, Roe and Ross, 1984:198) creative reading is concerned with the production of new ideas, development of new insights, fresh approaches, and original constructs. Creative readers must be skilled in the areas discussed below:

\section{Cause and effect}

Creative readers must understand cause and effect relationships in a story so well that they know why a character acts he or she does at a particular time. Such readers will also be able to imagine what might have happened in a story if a particular event had not occurred or if something quite different had happened.

\section{Visualization}

By vividly visualizing the events depicted by the author's words, creative readers allow themselves to become a part of the story-they see the colors, hear the sound, feel the textures, taste the flavors, and smell the odors described by the writer.

\section{Making value judgments}

Creative readers need to be able to determine whether actions of characters are reasonable or unreasonable.

\section{Solving problems}

Creative readers relate the things they read to their own personal problems, sometimes applying the solution of a problem encountered in a story to a different situation.

\section{Predicting outcomes}

In order to predict outcomes, readers must put together available information and note trends, and then project the trends into the future, making decisions about what events might logically occur next. A creative reader is constantly predicting what will happen next in a story, reacting to the events he or she is reading about and drawing conclusions about their result. Creative reading requires readers to think as they read, just as critical reading does, and it also requires them to use their imaginations. 


\subsection{Narrative Text}

Narrative text is any completed act of communication such as greeting between friends in the street, a television advertisement, a novel or a film and so on (Knapp and Watkins, 2005:29). In other words, text is the act of communication for human that is used to communicate with others.

The genre of narrating or narrative is one of the most commonly read, though least understood of all the genres. Because a narrative has been and continues to be such as a popular genre, there is a belief that is a genre that students pick up and write naturally. Story- writing, therefore, has been prominent as a means of naturally inducting students into the intricacies and idiosyncrasies of the English language (Knapp and Watkins, 2005:220). The purpose of narrative text is to recount a personal of fictional experience or to tell a story based on a real or imagined event.

The generic structures of narrative text are:

1. Orientation: sets the scene and when the story happened, introduces the participants of the story: who and what is involved in the story.

2. Complication: tells beginning of the problem which leads to the crisis (climax) of the main participants.

3. Resolution: the problem (crisis) is resolved, either in a happing ending on said (tragic) ending, for better or worse.

4. Coda (optional)

The example of narrative text:

\section{The Smartest Parrot}

Once upon time, a man had a wonderful parrot. There was no other parrot like it. The parrot could say every word, except one word. The parrot would not say the name of the place where it was born. The name of the place was Catano.

The man felt excited having the smartest parrot but he could not understand why the parrot would not say Catano. The man tried to teach the bird to say Catano however the bird kept not saying the word.

At the first, the man was very nice to the bird but then he got very angry. "You stupid bird!" pointed the man to the parrot. "Why can't you say the word? Say Catano! Or I will kill you" the man said angrily. Although he tried hard to teach, the parrot would not say it. Then the man got so angry and shouted to the bird over and over; "Say Catano or I'll kill you". The bird kept not to say the word of Catano.

One day, after he had been trying so many times to make the bird say Catano, the man really got very angry. He could not bear it. He picked the parrot and threw it into the chicken house. There were four old chickens for next dinner "You are as stupid as the chickens. Just stay with them" Said the man angrily. Then he continued to humble; "You know, I will cut the chicken for my meal. Next it will be your turn, I will eat you too, stupid parrot". After that he left the chicken house.

The next day, the man came back to the chicken house. He opened the door and was very surprised. He could not believe what he saw at the chicken house. There were three death chickens on the floor. At the moment, the parrot was standing proudly and screaming at the last old chicken; "Say Catano or I'll kill you".

The analysis of the generic structure:

Orientation: Once upon time, a man had a wonderful parrot. There was no other parrot like it. The parrot could say every word, except one word. The parrot would not say the name of the place where it was born. The name of the place was Catano.

Complication: It explores the conflict in the story. It will show the crisis, rising crisis and climax of the story. In the parrot story, paragraph 2, 3, 4 are describing the complication. 
Readers will find that the man face a problem of why the parrot cannot say Catano. To fix this problem, the man attempted to teach the bird.

Resolution: It shows the situation which the problems have been resolved. It must be our note that "resolved" means accomplished whether succeed or fail. In the last paragraph of the smartest parrot story, readers see the problem is finished. The parrot could talk the word which the man wanted. The parrot said the word with higher degree than the man taught the word to it. That was the smartest parrot.

\subsection{Approach, Method, Technique, and Strategy}

It is not easy for teachers to classify the term approach, methods, and strategy. It is due to the very slight different meanings in which may be overlapped among the terms.

\subsubsection{Approach}

According to Setiyadi (2006:8) an approach is a set of correlative assumptions dealing with the nature of language and the nature of language learning and teaching. Approach is the level at which assumptions and beliefs about language, language learning and language teaching. Different people may agree with different beliefs and assumptions dealing with the nature of language, learning and teaching. Assumptions or beliefs may be taken for granted. People do not have to come to an agreement about the assumptions.

Therefore in language teaching there are three different assumptions about language and language teaching. Richards \& Rogers (2001:20-21) in Setiyadi (2006:8) stated that at least three are different views of the nature of language namely: (1) the structural view sees language as a system of structurally related elements, (2) the functional view regards language as a vehicle for the expression of functional meaning. This view emphasizes not only elements of grammar as the structural view does but also topic or concepts that language learners need to communicate about, (3) the interactional view, the view that language is a vehicle for the realization of interpersonal relations and social interactions between individuals.

An approach describes how people acquire their knowledge of the language and make statement about the condition which will promote successful language learning.

\subsubsection{Method}

Anthony (1963:63) defines a method is an overall plan for the orderly presentation of language material, no part of which contradicts, and all of which is based upon the selected approach there can be many methods. In addition, Anthony (1963:63) clarifies a method as a level at which theory is put into practice and at which choices are made about the particular skill to be taught, the content to be taught, and the order in which the content will be presented.

Setiyadi (2006:12) states, "Method is the plan of language teaching that is consistent with the theories". Method should come after approach because the plan of language teaching should be develop from theories on the nature of language and language learning. In addition, Mackey (1975:155) in Setiyadi (2006:12) clarifies a method is a set of teaching procedures. The term method in direct method may refers to a single aspect of language teaching: presentation of material.

\subsubsection{Technique}

Anthony (1963:63) states that a technique is an implementation that which actually takes place in a classroom. It is a particular trick, stratagem, or contrivance used to accomplish an immediate objective. Technique must be consistent with a method, and therefore in harmony with an approach as well. In other words, a language learning technique is an explicit procedure or strategy to accomplish a particular learning objective or set of objectives. Anthony added technique is the level at which classroom procedure are described. 
Setiyadi (2006:14) states" A technique is implementation, it means a technique is something that actually takes place in language teaching or learning in the classroom." All activities that take place in a language class are techniques. Techniques are not exclusive to certain methods. To some extent, different methods may have some similar techniques even though they must have other different techniques.

Language teaches may develop their own techniques as long as the technique are still consistent with the assumptions or theories of the methods from which technique derive.

\subsubsection{Strategy}

According to David (1976) in Sanjaya (2009:124) strategy is a plan, method or series of activities designed to achieve a particular educational goal. First, learning strategy is a plan of action or series of activities including use methods and use various sources of learning. It means that preparation of a new strategy to process of the work plan has not been up on the action. Second, strategy is designed to achieve specific goals. Its means the preparation the study use a variety of facilities and learning resources all geared to achieving the objective.

\subsection{Semantic Mapping Strategy}

Semantic mapping strategy is not a new strategy. It has been around for a long time and it has been called by several different names. Some have used the term cognitive networks and other labels that have been used for procedure are semantic webbing, semantic networks, and plot maps. According to Hanf (1971: 26) semantic mapping strategy is a simple technique of structuring information in graphic form, is as old as. For the purpose of vocabulary expansion, semantic mapping strategy extends knowledge by display, in categories, world related to another word. It diverse from semantic attributes listing essentially by showing the categories.

In addition, Heimlich \& Pittelman (1986:44) explain that semantic mapping strategy is one type of graphic organizer. It helps students visually organize and graphically show the relationship between one piece of information and other.

The strategy has been identifying researchers as an excellent technique for increasing vocabulary and improving reading comprehension. Semantic mapping strategy can be used to find out the content and meaning of the vocabulary in narrative text form.

\subsubsection{Procedure of Using Semantic Mapping Strategy}

In general, the process of using semantic mapping strategy focuses on the organization of concepts represented in a concrete form. The relationship among major concepts and their supporting details are presented visually. The students, actively involved in the process of developing the map, is stimulated to relate prior knowledge to the new material being read or studied (Heimlich \& Pittelman, 1986:86). The following steps are the instructional procedures of using semantic mapping strategy in teaching-learning process. These procedures can be varied to suit different purposes:

1) Select a word central to the story to be read, or from any other source of classroom interest or need.

2) Write the word on the chalkboard 
3) Ask the class to think as many word as they can which are in some way related to the word teacher have written, and jotted them on paper.

4) Have individuals share the words they have written and as they do, write them on the board and attempt to put them into categories, for example, if the word teacher writes on the board is school, a complete format of semantic mapping strategy is presented in figure 2.1 .

5) The teacher might want to number the categories and have the students name them : school subject, things we used in school, places in school and kinds of school.

6) As with semantic attribute listing, discussion is critical to the success of Semantic Mapping. The meaning and uses of new word, new meaning for known words, seeing "old" words in a new light, and seeing the relationship among word desirable (and evitable) are outcomes semantic mapping strategy. It is advisable to be ready for some disagreement: A teacher may have put a word in one category when it can as sensibly have been put in a different category. Some word will end up in several categories. New word will typically be added as the discussions issues.

7) As time permits, select one word from the existing semantic mapping strategy and begin to develop a new one. For example, barbers or boring or brick from school map could each generate extensive maps.

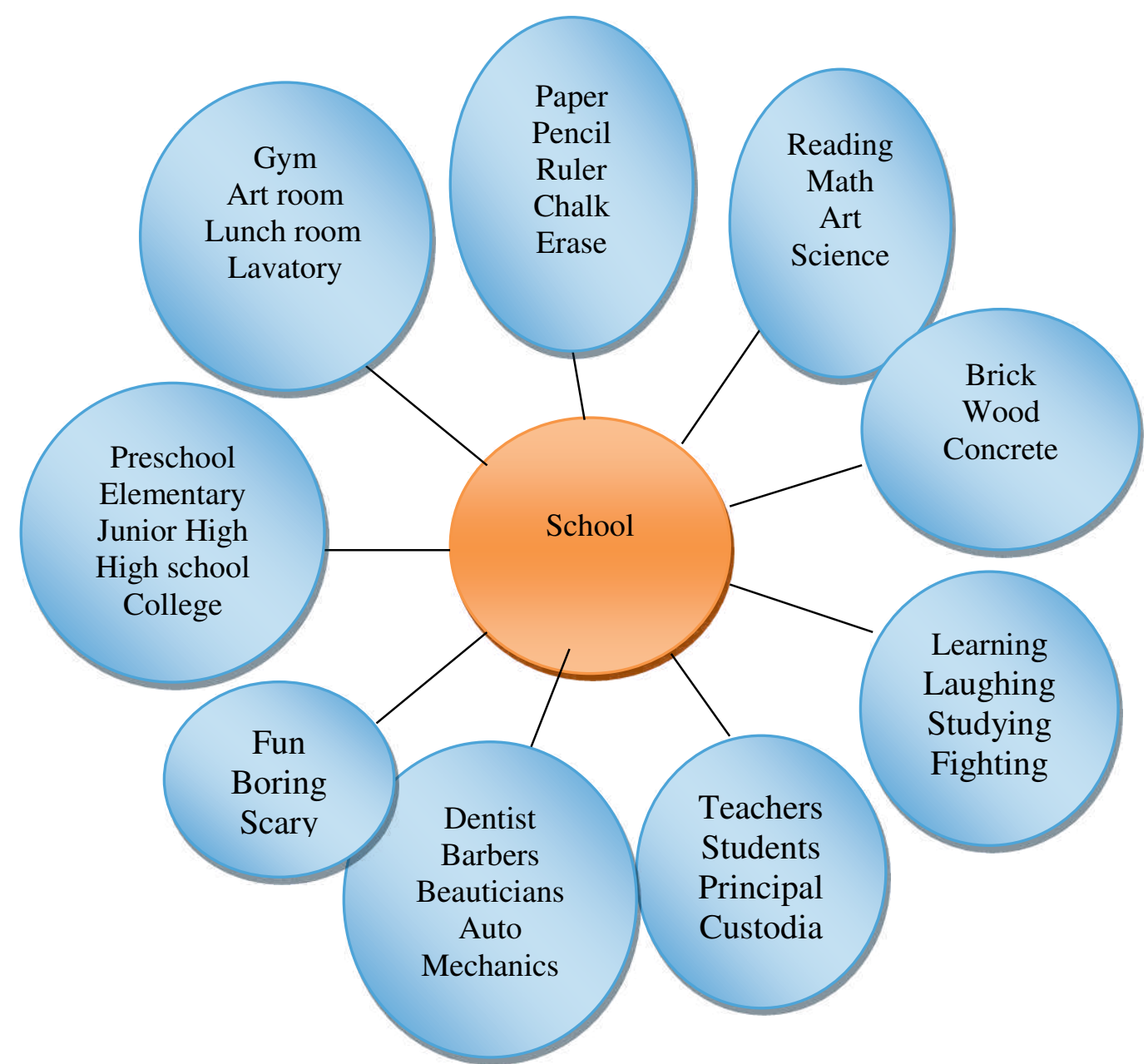

Figure 2.1 Semantic Mapping Strategy Model (Burns, Roe \& Smith, 1984:74) 


\subsubsection{Advantages of Applying Semantic Mapping Strategy}

Heimlich \& Pittelman (1986:44) present a set of advantages related to the semantic mapping strategy. These advantages are: motivating the students of all grade levels, integrating thinking with reading, integrating assessment with teaching, and making a judgments concerning the appropriate instruction needed. Heimlich \& Pittelman (1986:46) assert that: "Semantic mapping appears to motivate students of all age levels and to involve them actively in the thinking process. The process of semantic mapping also allows teachers to assess and interpret what students know as well as make judgments concerning the appropriate instruction needed."

These judgments can be based upon what students demonstrate they already know about a topic, rather than teachers having to assume what the students know. Heimlich \& Pittelman (1984: 5) explained that semantic map is one type of graphic organizer. It helps students visually organize and graphically show the relationship between one piece of information and another. This strategy has been identified as an excellent strategy for increasing vocabulary and improving reading comprehension.

One common trait found among semantic mapping strategy is that they show the order and completeness of a student's thought process - strengths and weakness of understanding become clearly evident. Many semantic maps show different aspects of an issue in close and also the big picture, since many semantic maps use short words or phrases, they are ideal for many types of learners, including English Language readers with intermediate proficiency. Tree maps can be used to show classifications, analysis, structures, attributes, examples and brainstorming.

In conclusion, many studies have proved that semantic mapping gives many advantages in teaching-learning process especially for students. They showed the effects of using semantic mapping do not only improve the students' reading comprehension, but also their thinking, brainstorming and writing abilities.

\subsubsection{Disadvantages of Semantic Mapping Strategy}

It is hard for the writer to finds evidences which proved the disadvantages of semantic mapping strategy in the learning process. Almost the studies that have been done by researchers found that students' ability improved when they use this strategy in reading activity.

Grabe \& Stoller (2002:34) point out that the potential overuse of semantic mapping must be avoid in second language context where students may be easily overloaded. The function of semantic mapping is to introduce words in a certain category, so the words in the map are always semantically or syntactically similar. Students are often confused, for example, some students take cabbage for carrot, British or Britain. The worst performance takes place in the linked words or representation includes both similar and different features, such as in the case of synonyms or antonyms. Thus teaching a pair of words like prevents and protects, open and shut makes learning more difficult.

\section{RESEARCH METHOD}

\subsection{Research Design}

This research was quantitative experimental research design, with try out, pretest, and posttest design. Best \& Khan (2002: 146) state "Research design is the blueprint of the procedures that enable experimental research was used to investigating whether or not semantic mapping strategy significantly affects students' ability reading comprehension of narrative text."

There are two variable in this research, namely the independent variable was semantic mapping strategy while the dependent variable was reading comprehension. In this research the strategy used to the experimental design which consisted of two group, namely experimental group and control group. 
Best \& Khan (2002:135-136) stated that an experiment involves the comparison of the effects of particular treatment with that of a different treatment or of no treatment. In a simple conventional experiment, reference is usually made to an experimental group and to a control group. The experimental group is exposed to the influence of the factors under consideration; the control group is not.

The experimental group taught by using semantic mapping strategy, while control group without semantic mapping strategy. Both of groups given pre-test and post-test in order to know the differences of average scores:

Table 3.1 Research Design

\begin{tabular}{|l|c|c|c|}
\hline \multicolumn{1}{|c|}{ Group } & Pretest & Treatment & Posttest \\
\hline $\begin{array}{l}\text { Experimental group } \\
\text { (EG) }\end{array}$ & Y1 & X & Y2 \\
\hline Control Group (CG) & Y1 & Y & Y2 \\
\hline
\end{tabular}

Where:

EG : Experimental group

CG : Control group

$\mathrm{X}$ : Using Semantic Mapping Strategy

Y : Without Semantic Mapping Strategy

Y1 : Pre test

Y2 : Post test

The experimental group was given the treatment. The write taught the experimental group by applying the semantic mapping strategy. The treatment was being expected to give good effect on reading comprehension. Meanwhile, the writer taught the control group by applying the conventional method. An experimental group is the group in a scientific experimental where the experimental group procedure is performed. This group is exposed to the independent variable being tested and the changes observed and recorded. A control group is a group separated from the rest of the experiment where the independent variable being tested cannot influence the result. This isolates the independent variable's effects on the experiment and can help rule out alternate explanations of the experimental results.

\subsection{The Location and Time of the Research}

The research was conducted at SMP Swasta Raksana Medan which is located at Jl. Gajah Mada No.20 Medan. The writer conducted this research in this school because there is no ever any research with the title of this research. This research was conducted in July 2014.

\subsection{Population and Sample}

The writer had determined the object of the study consist of the population and sample. The explanation on the object of the study is as follow:

\subsubsection{Population}

Best \& Khan (2002:13) state" Population is any group of individuals that have one or more characteristics in common that are of interest to the researcher." The population maybe all the individuals of particular type, or a more restricted part of that group. This kind of group is taken into sample of research so that the writer can generalize the result of the study. The population of this study is the students of SMP Raksana Medan in academic years 2014 / 2015, Jln Gajah Mada No.20 Medan. There are two (2) classes of 
IX. Each class has same number of students. The total number of the students is 60 students. In this study, the writer have chosen the ninth year students because at this level have studied narrative text.

\subsubsection{Sample}

Best \& Khan (2002:13) state," a sample is a small proportion of a population selected for observation and analysis." By observing the characteristics of the sample, one can make certain inferences about the characteristics of the population from which it is drawn. Sample of the study is the two classes with 60 students are selected. Each of two classes consisted of 30 students and 30 students. The sample was divided into two groups. The first group as experimental group (EG) and the second group as control group (CG). The sample of this research was the students of IX-1 and IX-2 of SMP Swasta Raksana Medan in academic year 2014/2015.

\subsection{Instrument for Collecting Data}

In collecting the data, the writer given the multiple - choice test which taken from the English reading comprehension test on UN's (Ujian Nasional) of SMP. It is administer as the instrument to obtain the data. The procedure in administrating the test were divided into pre-test, treatment, post-test and scoring the test. Each of this session is discussed below.

\section{Pre-test}

The pre-test was conducted to find out the homogeneity of the sample. It was used to determine whether the two groups are relatively equal in reading. The homogeneity can be seeing from the average score of each group. Before starting the experiment, a pretest was administrated to the samples both groups with the same items.

\section{Treatment}

The treatment was conducted after the administration of the pre-test. The experimental group was taught by applying semantic mapping strategy to improve reading comprehension. The process of the experimental group was conducted in three meetings. The activities during the treatment was by applying semantic mapping strategy in teaching reading comprehension in the experimental group in general can be described in table 3.2.

\section{Table 3.2 Teaching Procedure of the Experimental Group}

\begin{tabular}{|c|c|c|}
\hline Meetings & Teacher & Students \\
\hline \multirow[t]{5}{*}{ I } & $\begin{array}{l}\text { 1. Teacher opened the class by greeting, } \\
\text { introduces herself and explained about } \\
\text { what are she going to do this meeting }\end{array}$ & $\begin{array}{l}\text { 1.The students responded the teacher's } \\
\text { greeting and paid attention to the teacher's } \\
\text { explanation. }\end{array}$ \\
\hline & $\begin{array}{l}\text { 2. Teacher distributed the copies of a } \\
\text { reading text to the students. }\end{array}$ & $\begin{array}{l}\text { 2. The students took the copies of a reading } \\
\text { text. }\end{array}$ \\
\hline & $\begin{array}{l}\text { 3. Teacher explained brief information } \\
\text { semantic mapping strategy and asked the } \\
\text { students to do this strategy by reading a } \\
\text { narrative text on the paper. }\end{array}$ & $\begin{array}{l}\text { 3. The students read the text and done what } \\
\text { the teacher's said }\end{array}$ \\
\hline & $\begin{array}{l}\text { 4. Teacher asked the students to answered } \\
\text { the questions based on the explanation }\end{array}$ & 4. The students answered the questions \\
\hline & $\begin{array}{l}\text { 5. The lesson closed by concluded the } \\
\text { material that have discussed. }\end{array}$ & $\begin{array}{l}\text { 5.The students listened to the teacher's } \\
\text { explanation and make some note about the } \\
\text { conclusion }\end{array}$ \\
\hline
\end{tabular}




\begin{tabular}{|c|c|c|}
\hline \multirow[t]{5}{*}{ II } & $\begin{array}{l}\text { 1. Teacher opened the class by } \\
\text { greeting and explained about what } \\
\text { are going to do this meeting }\end{array}$ & $\begin{array}{l}\text { 1. The students responded to the teacher's } \\
\text { greeting and paid attention to the teacher's } \\
\text { explanation }\end{array}$ \\
\hline & $\begin{array}{l}\text { 2. Teacher distributed the copies of a } \\
\text { reading text to the students. }\end{array}$ & 2. The students took a reading text. \\
\hline & $\begin{array}{l}\text { 3. Teacher explained brief information } \\
\text { semantic mapping strategy and asked the } \\
\text { students to do this strategy by reading a } \\
\text { narrative text on the paper }\end{array}$ & $\begin{array}{l}\text { 3. The students read the text and done what } \\
\text { the teacher's said }\end{array}$ \\
\hline & $\begin{array}{l}\text { 4. Teacher asked the students to answered } \\
\text { the questions based on the explanation }\end{array}$ & 4. The students answered the question \\
\hline & $\begin{array}{l}\text { 5. The lesson closed by concluding the } \\
\text { material }\end{array}$ & $\begin{array}{l}\text { 5. The students listened to the teacher's } \\
\text { explanation and make not about the } \\
\text { conclusion }\end{array}$ \\
\hline \multirow[t]{5}{*}{ III } & $\begin{array}{l}\text { 1. Teacher opened the class by greeting } \\
\text { and given explanation about what are } \\
\text { going to do this meeting }\end{array}$ & $\begin{array}{l}\text { 1. The students responded the teacher's } \\
\text { greeting and paid attention to the teacher's } \\
\text { explanation. }\end{array}$ \\
\hline & $\begin{array}{l}\text { 2. Teacher distributed the copies of the } \\
\text { material to the students. }\end{array}$ & $\begin{array}{l}\text { 2. The students took the material. Notice the } \\
\text { teacher's explanation and response it }\end{array}$ \\
\hline & $\begin{array}{l}\text { 3. Teacher explained brief information } \\
\text { semantic mapping strategy and asked the } \\
\text { students to do this strategy by reading a } \\
\text { narrative text on the paper. }\end{array}$ & $\begin{array}{l}\text { 3. The students read the text and done what } \\
\text { the teacher's said }\end{array}$ \\
\hline & $\begin{array}{l}\text { 4. The Teacher asked the students to } \\
\text { answer the question individually based the } \\
\text { text. }\end{array}$ & $\begin{array}{l}\text { 4. The students answered the question } \\
\text { individually }\end{array}$ \\
\hline & $\begin{array}{l}\text { 5. The lesson closed by concluded the } \\
\text { material }\end{array}$ & $\begin{array}{l}\text { 5. The students listened to the teacher's } \\
\text { explanation and make some note about the } \\
\text { conclusion. }\end{array}$ \\
\hline
\end{tabular}

The control group also was conducted in three meetings. The activities during the treatment was by used conventional strategy in teaching reading in the control group in general can be described in Table 3.3.

Table 3.3 Teaching Procedure of the Control Group

\begin{tabular}{|c|l|l|}
\hline Meetings & \multicolumn{1}{|c|}{ Teacher } & \multicolumn{1}{|c|}{ Students } \\
\hline \multirow{3}{*}{ I } & $\begin{array}{l}\text { 1.Teacher opened the class by greeting, } \\
\text { introduces herself and explanation about } \\
\text { what are going to do this meeting }\end{array}$ & $\begin{array}{l}\text { 1.The students responded the teacher's } \\
\text { greeting and paid attention to the } \\
\text { teacher's explanation }\end{array}$ \\
\cline { 2 - 3 } & $\begin{array}{l}\text { 2. Teacher distributed of copies a reading } \\
\text { text to the students. }\end{array}$ & 2. Students took the material. \\
\cline { 2 - 3 } & $\begin{array}{l}\text { 3. Teacher asked the students to read the } \\
\text { text one by one loudly answering the } \\
\text { questions. }\end{array}$ & 3. The students read the text. \\
\hline
\end{tabular}




\begin{tabular}{|c|c|c|}
\hline & $\begin{array}{l}\text { 4. The teacher asked the students to found } \\
\text { out the difficult word and found the } \\
\text { meaning of the text }\end{array}$ & $\begin{array}{l}\text { 4. The students found out the difficult } \\
\text { word and find the meaning of the text. }\end{array}$ \\
\hline & $\begin{array}{l}\text { 5. The teacher asked the students to answer } \\
\text { the questions. The lesson closed by the } \\
\text { concluding the material }\end{array}$ & $\begin{array}{l}\text { 5. The students listened to the teacher's } \\
\text { explanation }\end{array}$ \\
\hline \multirow{5}{*}{ II } & $\begin{array}{l}\text { 1. Teacher opened the class by greeting } \\
\text { and explaining about what are going to do } \\
\text { this meeting }\end{array}$ & $\begin{array}{l}\text { 1. The students responded the teacher's } \\
\text { greeting and paid attention to the } \\
\text { teacher's explanation }\end{array}$ \\
\hline & $\begin{array}{l}\text { 2. Teacher distributed of copies of a } \\
\text { reading text to the students }\end{array}$ & 2. The students took the material \\
\hline & $\begin{array}{l}\text { 3. Teacher asked the students to read the } \\
\text { text one by one loudly answering the } \\
\text { questions. }\end{array}$ & 3. The students read the text \\
\hline & $\begin{array}{l}\text { 4. The teacher asked the students to found } \\
\text { out the difficult word and found the } \\
\text { meaning of the text }\end{array}$ & $\begin{array}{l}\text { 4. The students found out the difficulties } \\
\text { words and found the meaning of the text. }\end{array}$ \\
\hline & $\begin{array}{l}\text { 5. The teacher asked the students to answer } \\
\text { the questions. The lesson close by the } \\
\text { concluded the material }\end{array}$ & $\begin{array}{l}\text { 5. The students listened to the teacher's } \\
\text { explanation }\end{array}$ \\
\hline \multirow{5}{*}{ III } & $\begin{array}{l}\text { 1. Teacher opened the class by greeting } \\
\text { and explained about what are going to do } \\
\text { this meeting }\end{array}$ & $\begin{array}{l}\text { 1. The students responded the teacher's } \\
\text { greeting and paid attention to the } \\
\text { teacher's explanation }\end{array}$ \\
\hline & $\begin{array}{l}\text { 2. Teacher distributed of copies the } \\
\text { material to the students }\end{array}$ & 2. The students took the material \\
\hline & $\begin{array}{l}\text { 3. Teacher asked the students to read the } \\
\text { text one by one loudly answered the } \\
\text { questions. }\end{array}$ & 3. The students read the text \\
\hline & $\begin{array}{l}\text { 4. The teacher asked the students to find } \\
\text { out the difficult word and find the meaning } \\
\text { of the text }\end{array}$ & $\begin{array}{l}\text { 4. The students found out the difficult } \\
\text { word and found out the meaning of the } \\
\text { text. }\end{array}$ \\
\hline & $\begin{array}{l}\text { 5. The teacher asked the students to answer } \\
\text { the questions. The lesson was close by the } \\
\text { concluding the material }\end{array}$ & $\begin{array}{l}\text { 5. The students listened to the teacher's } \\
\text { explanation }\end{array}$ \\
\hline
\end{tabular}

\section{Posttest}

After the teaching presentation, both the experimental group and the control group were given a post test. The post test was similar to the test that is lead in pre-test. The writer given the students a post tests in order see the result whether the strategy is 
effective or not. It is also to measure the students' competence in reading comprehension after the treatment done. The result of this text would analyze to evaluate the two groups.

\subsection{Scoring the Test}

In scoring the test, this study used score ranging 0-100 by counting the correct answer and applying this formula:

$\mathrm{S}=\frac{\mathrm{R}}{\mathrm{N}} \times 100$

Where:

S : score of the test

$\mathrm{R}$ : the correct answer

$\mathrm{N}$ : number of the question

\subsection{Validity and Reliability of the Test}

Best \& Khan (2002:208) state, "Reliability and validity are essential to the effectiveness of any data -gathering procedure." These terms are defined here in the most general way. The establishment and procedure of each aspect was discussed in the following parts:

\subsubsection{Validity of the Test}

Best \& Khan (2002:208) state, "Validity is that quality of the data-gathering instrument or procedure that enables it to measure what it is supposed to measure." A test would be really able to measure what it is intended to measure. Arikunto (2003:196) stated that the validity question is concerned with the extent to which an instrument measures what one thinks it measuring. It is absolutely essential that the writer as this question" so, in this case the validity of the text is measured whether the test is really measured the reading comprehension.

The validity of the test material in this study would check through the content validity. It is form a validity which is based on the degree to which a test adequately and sufficiently measures the particular skill or behavior is set out to measure. The data would calculate with formula Spearman Brown product moment:

Where :

$$
r_{x y}=\frac{N(\Sigma X Y)-(\Sigma X)(\Sigma Y)}{\sqrt{\left\{N\left(\Sigma X^{2}\right)-(\Sigma \mathrm{X})^{2}\right\}\left\{\mathrm{N}\left(\Sigma \mathrm{Y}^{2}\right)-(\Sigma \mathrm{Y})^{2}\right.}}
$$

$r_{x y} \quad$ : validity of the coeficient

$\mathrm{X} \quad$ : sum of the students with correct answer

$\mathrm{Y} \quad$ : sum of the students with incorrect answer

$\mathrm{N} \quad$ : number of the students

\subsubsection{Reliability of the Test}

Best \& Khan (2002:208) argued that reliability is the degree of consistency that the instrument or procedure demonstrates: Whatever it is measuring, it does so consistently. Reliability is a necessary but not sufficient condition for validity. The data calculated by the Kuder - Richardson 21 formula. The Kuder Richardson in Arikunto (2010:189) is formulated as follow:

$$
\mathrm{KR}_{21}(\mathrm{r})=\frac{\mathrm{k}}{\mathrm{k}-1}\left(1-\frac{\mathrm{m}(\mathrm{k}-\mathrm{m})}{\mathrm{ks}^{2}}\right)
$$


Where :

$\mathrm{R} \quad$ : reliability of the test

$\mathrm{K}$ : number of items in the students

M : mean score of the students

SD : standard deviation

To complete the mean of the test, the writer use the following:

$\mathrm{M}=\sum \frac{\mathrm{X}}{\mathrm{N}}$

Where:

M : mean of the score

$\sum \mathrm{x}$ : the sum of the score

$\mathrm{N}$ : sum of the students

$S=\sqrt{\frac{\sum X^{2}}{n}}$

Where:

S : standard deviation

$\sum \mathrm{x}$ : the sum of the score

$\mathrm{N} \quad$ : sum of students

According to Best $\&$ Khan (2002:308) the coefficient of (r) can be interpret using these criteria as follow:

$0.0-0.20 \quad$ : negligible

$0.21-0.40 \quad:$ low

$0.41-0.60 \quad$ : moderate

$0.61-0.80 \quad$ : substantial

$0.81-1.00 \quad$ : high to very high.

\subsection{Technique of Analyzing the Data}

To test the hypothesis, the writer used the t- test formula as the following:

$$
\mathrm{t}=\frac{\mathrm{Ma}-\mathrm{Mb}}{\sqrt{\left\{\frac{\mathrm{da^{2 } + \mathrm { db } ^ { 2 }}}{\mathrm{Na}+\mathrm{Nb}-2}\right\}\left\{\frac{1}{\mathrm{Na}}+\frac{1}{\mathrm{Nb}}\right\}}}
$$

Where:

Ma : mean score of experimental group

$\mathrm{Mb}$ : mean score of the control group

$\mathrm{Da}^{2} \quad$ : score of the experimental group

$\mathrm{Db}^{2} \quad$ : score of control group

$\mathrm{Na}$ : number of experimental group

$\mathrm{Nb} \quad$ : number of control group 


\section{DATA AND DATA ANALYSIS \\ 4.1 Data}

This study was conducted by applying experimental research. There are two groups in this research, namely the experimental group and the control group. The treatment was done to the experimental group while there was no treatment given to the control one. In order words, students in the experimental group were taught by using semantic mapping strategy while students in the control group were taught by using conventional method.

The population in this research is the students of the ninth grade of SMP Raksana Medan in the Academic Year of 2014/2015. The sample taken namely class IX-1, which decided as an experimental group and IX-2 which as a control group. The research was conducted on $14^{\text {th }}$ of July $-19^{\text {th }}$ of July 2014 . The treatment was given to the experimental group in one meeting after administering the pretest. Comparing to both of two groups during the teaching process, the students in the experimental group had better comprehension in reading text than those in the control group. The students in the experimental group were taught how to read the text critically and how to find the information needed by applying semantic mapping strategy while in the control group taught by using conventional method. As result, they had some difficulties in comprehending the text well. After administering the treatment, the posttest was done to both to measure the students' reading comprehension.

This research applied an objective test called multiple-choice test which consists of 20 items. The total score was 100. The research was conducted, the writer got the data of students' scores in pretest and posttest from the experimental and control groups.

The mean score in experimental group of pretest is 54 and the posttest is 78.33. There are different numbers which show there is achievement of students' reading comprehension after teaching process. The lowest score for pretest is 45 and the highest score is 65 , while for posttest, the lowest score is 70 and the highest score is 90 . The different score between the pretest and the posttest shows that there is an increasing of students' reading comprehension after having been taught by using Semantic Mapping strategy.

Moreover, the total score in control group of pretest is 1520 and the posttest is 2025. The mean score in control group of pretest is 50.67 while the post - test is 67.5. Based on the data above, it proves that there is significant difference of the score between the two groups. The increase of students' score in experimental group is higher than that of in control one.

\subsection{Data Analysis}

After collecting and analyzing the data by using $\mathrm{t}-$ test formula, the writer found that the value of $t$ - test (4.779) exceeds the value of $t-$ table (2.00). Thus, Hypothesis Alternative is accepted. This finding shows that hypothesis is really true in this research. It indicates that the students' reading comprehension taught by using Semantic Mapping Strategy is higher than those taught by using conventional strategy as showed in the total score of the experimental group in the pretest is 1620 but in the posttest is 2350 and in the pretest of the control group is 1520 but in the posttest is 2025 .

\section{CONCLUSIONS AND SUGGESTIONS \\ 5.1 Conclusions}

Based on the data analysis, it was concluded that:

1) The use of Semantic Mapping Strategy significantly affects the students' reading comprehension especially for the students in the class IX-1 SMP Swasta Raksana Medan. It was shown by the increasing of the students' mean from the pre-test up to the post-test. The students' mean of the pre-test was 63.00 , the post-test 83.83 . From the 
result, it was concluded that the application of the Semantic Mapping Strategy had successfully increase students' reading comprehension.

2) The Semantic Mapping Strategy can be applied for Junior High School students. It really works if it is applied in a small class consisting of $\leq 30$ students, but it is not applicable for a big class consisting of more than 30 students. The achievement of students Class I-X at SMP Swasta Raksana Medan in the Academic Year of 2014/2015 in reading comprehension increased after they taught reading comprehension through the application of the Semantic Mapping Strategy . The Semantic Mapping Strategy is a quite good strategy to improve students' reading comprehension skill and increase their involvement in classroom activities.

\subsection{Suggestions}

In teaching the English language especially reading comprehension, English teachers are suggested to do the following:

1) English teachers especially whose primary task is to teach reading should teach reading by applying the Semantic Mapping Strategy because it can create a pleasure and exciting learning atmosphere so that students feel more motivated and interested in learning reading skill.

2) Students of English Language Education Study Program of Taechers Training and Education Faculty especially who have a major interest in learning reading skill should try applying the Semantic Mapping Strategy in comprehending English reading materials because it can help you develop your thinking, review materials, and check your prior knowledge.

\section{BIBLIOGRAPHY}

Anthony, E. M. 1963. Approach, Method and Technique in Teaching As A Second Language. New York: McGraw-Hill.

Arbaiyah, Ali \& Zidah Samad. 2001. Peningkatan Penguasaan Bahada Inggeris Melalui Latih Tubi Untuk Memperkayakan Perbendaharaan Kata ke Arah Pemahaman Teks Dengan Penggunaan Tata Bahasa Yang Betul. BPPDP: Kementerian Pendidikan Malaysia.

Arikunto,S. 2003. Prosedur Penelitian : Suatu Pendekatan Praktik. Jakarta: Rineka Cipta.

.2010. Prosedur Penelitian: Suatu Pendekatan Praktik: Edisi Revisi V Jakarta: Rineka Cipta.

Best, John W. and James V. Kahn. 2002. Research in Education ( $7^{\text {th }}$ Ed). New Delhi: Prentice Hall of India.

Burns, A., Roe , J. \& Ross, P. 1984. Teaching in Today's Elementary School $\left(3^{\text {rd }}\right.$ ed.). New York: Longman. 
Burns, A., Roe , J. \& Smith. S.H. 1984. Teaching in Today's Elementary School ( $3^{\text {rd }}$ ed.). Boston: Houghton Mifflin Company.

Gerot, L \& Wignel, P. 1994. Making Sense on Functional Grammar. Sydney: Gerd Stabler.

Grabe, W. \& Stoller, F. 2002. Teaching and Researching Reading. Harlow: Pearson Education Limited.

Hanf, M. 1971. Mapping: a technique for translating reading into thinking, Journal of reading, 225-223. In Keshavarz, M. et.al. The Effect of Semantic Mapping Strategy Instruction on Vocabulary Learning of Intermediate EFL Students. Journal of Faculty Letters and Humanities. Accessed from http://www.ensani.ir/storage/files/201102151406225.PDF_on Saturday 26 April 2014.

Heilman, Arthur W., Timothy R. Blair, and William H. Rupley. 1981. Principles and Practices of Teaching Reading ( $5^{\text {th }}$ Ed). Ohio: Bell \& Howell Company.

Heimlich, J.E \& Pittelman, S.D.1986. Semantic Mapping: Classroom Application. Delaware: International Reading Association.

Knap, P. \& Watkins, M. 2005. Writing English Language Text: Longman Handbooks for Language Teaching. New York: Longman.

Nunan, D. 2003. Practical English Language Teaching. New York: Mc Graw Hill.

Sanjaya, Wina. 2009. Strategi Pembelajaran Berorientasi Standar Proses Pendidikan. Jakarta: Kencana.

Setiayadi, 2006. Teaching English As A Foreign Language. Yogyakarta: Graha Ilmu.

Turner, T.N. 1988. Comprehension Reading for Meaning. Illionis: Scott, Foresman \& Co. 